\title{
Qualitative characterisation of cultivated and wild edible plants: Mineral elements, phenols content and antioxidant capacity
}

\author{
Grazia Disciglio, Annalisa Tarantino, Laura Frabboni, Anna Gagliardi, Marcella Michela \\ Giuliani, Emanuele Tarantino, Giuseppe Gatta
}

Department of Agricultural, Food and Environmental Sciences, University of Foggia, Italy

\begin{abstract}
This study investigated the qualitative characteristics of several edible wild herbaceous species, including those most consumed in Foggia Province (southern Italy). Analysis of qualitative characteristics was performed for the edible parts of 11 wild species (Beta vulgaris L., Foeniculum vulgare Miller, Centaurea solstitialis L., Cichorium intybus L., Scolymus hispanicus L., Sonchus oleraceus L., Borago officinalis L., Diplotaxis erucoides L., Diplotaxis tenuifolia (L.) DC, Sinapis arvensis L., Portulaca oleracea L.) and three cultivated species (C. intybus, B. officinalis, D. tenuifolia). The plants were collected from areas in the Foggia countryside, and the edible part of each species was analysed for dry matter, protein, cation and anion contents as well as total phenols and antioxidant activities. Among the cations, calcium was the most differentiated among species, ranging $784 \mathrm{mg} \mathrm{kg}^{-1}$ fresh weight (Fw) for B. vulgaris to $5886 \mathrm{mg} \mathrm{kg}^{-1} \mathrm{Fw}$ for $S$. hispanicus. The nitrate contents were also highly variable, from $75 \mathrm{mg} \mathrm{kg}^{-1}$ $\mathrm{Fw}$ for $C$. intybus to $3874 \mathrm{mg} \mathrm{kg}^{-1} \mathrm{Fw}$ for D. tenuifolia. Total polyphenols ranged from $1054 \mathrm{mg}$ gallic acid equivalents (GAE) $\mathrm{mg} \mathrm{kg}^{-1} \mathrm{Fw}$ for $C$. solstitialis to $3664 \mathrm{mg} \mathrm{GAE} \mathrm{mg} \mathrm{kg} \mathrm{m}^{-1} \mathrm{Fw}$ for $S$. arvensis. Antioxidant activities ranged from $839 \mathrm{mg}$ Trolox equivalents (TE) $\mathrm{kg}^{-1} \mathrm{Fw}$ for $B$. vulgaris to $5658 \mathrm{mg} \mathrm{TE} \mathrm{kg}^{-1} \mathrm{Fw}$ for $C$. intybus. Significant differences were also noted between wild and cultivated plants in the qualitative parameters. Total polyphenols and antioxidant activity were higher in wild $C$. intybus and $B$. officinalis than in their cultivated counterparts. Multivariate analysis (cluster analysis and linear discriminant analysis) allowed
\end{abstract}

Correspondence: Giuseppe Gatta, Department of Agricultural, Food and Environmental Sciences, University of Foggia, 71122 Foggia, Italy. Tel. +39-0881-589238

E-mail: giuseppe.gatta@unifg.it

Key words: Antioxidant activity; Wild edible plants; Cultivated plants; Polyphenols; Linear discriminant analysis.

Received for publication: 31 May 2017.

Revision received: 13 July 2017.

Accepted for publication: 15 July 2017.

(C) Copyright G. Disciglio et al., 2017

Licensee PAGEPress, Italy

Italian Journal of Agronomy 2017; 12:1036

doi:10.4081/ija.2017.1036

This article is distributed under the terms of the Creative Commons Attribution Noncommercial License (by-nc 4.0) which permits any noncommercial use, distribution, and reproduction in any medium, provided the original author(s) and source are credited. integration of the ANOVA data to determine the qualitative characteristics of the wild species that contribute most to group differences. The results of the present study aims to improve current knowledge about edible wild species as vegetable sources in the Mediterranean diet.

\section{Introduction}

Wild edible plants represent a particular aspect of the genetic biodiversity of vegetables and cultivated species as ecotypes and local varieties (Tarantino et al., 2011), and they are also an important food source, especially in the Mediterranean Basin (Boari et al., 2013; Hadjichambis et al., 2008). In this region, the environment is characterised by a great wealth of endemic flora, the diversity of which led to their use in the past as food for humans and animals as well as in folklore, veterinary medicine, cosmetics, food flavouring, beverages, energy production, crafts, and gardening (Marzi and Tedone, 2009).

In Europe, Italy is the country with the greatest plant biodiversity and hosts 6711 plant species (Conti et al., 2005). Several studies carried out over the last few decades have estimated that approximately 700 plant species belonging to 93 botanical families are used as vegetables or for seasoning (Bianco, 1989, 1990, 1997; Bianco and Machackova, 2002). The use of wild edible plants for food is a common practice in Italy (Aliotta, 1987; Candido et al., 2017), but those chosen for consumption vary across different regional districts. Some species are considered edible throughout the country, although they might only be collected and consumed within defined geographical areas.

In the Apulia region (southern Italy), there are numerous (approximately 2500) wild herbaceous species, of which 532 are consumed as food. All plant organs are edible including the leaves (for $80 \%$ of species) followed by the tender stems (36\%) and flowers $(20 \%) ; 75 \%$ of these plant parts are eaten boiled, $44 \%$ in salads, and $28 \%$ in soups (Bianco et al., 2009).

According to 3000 recipes from the southern regions of Italy, there were ancient dishes that incorporated wild edible plants, many of which were (and still are) used to prepare soups and stews, herb omelettes, and salads. However, the compositions of the dishes are very variable in terms of the number of species used; e.g., for a mixed soup, approximately 40 species were used to give the soup a balanced flavour by making it sweeter, more bitter and/or spicy (Marzi and Tedone, 2009).

Foggia is the northernmost Province of Apulia and is characterised by plains, valleys, hills, and mountains that rise up to 1151 $\mathrm{m}$ above sea level, and there are natural and semi-natural areas, uncultivated arable land, large areas with only sheep tracks, and banks along streams and gullies. Plants grow in all of these areas without the use of chemicals, and it is still possible to collect many 
species of edible wild plants, thus further promoting their traditional culinary uses. The knowledge of the use of these plants is deeprooted in Foggia province, where the older people are the connoisseurs and collectors of wild herbs and pass down this knowledge from father to son and mother to daughter. Many Italian people share a passion for food plants, and in Foggia province this is enriched by the produce in the local markets that constantly satisfy the needs of consumers.

The therapeutic and nutritional properties of wild edible plants have been the subject of numerous studies (Vitalini et al., 2006; Pardo de Santayana et al., 2007), and these plants are generally characterised by high nutritional but low energy values (Renna, 2017). Compared to their corresponding cultivated species, wild food plants have higher fibre content (Leonti et al., 2006), are richer in vitamins, minerals, polyphenols, antioxidants, and flavonoids (Pieroni et al., 2002), and have very low lipid levels (Trichopoulou et al., 2000). Natural products with antioxidant activity can enhance the endogenous defences of organisms against exposure to free radicals, and epidemiological evidence suggests that consuming a high amount of vegetables that are rich in phenolic compounds and that have high antioxidant activities in the diet is associated with a reduced incidence of coronary heart disease and some cancers (Cook and Samman, 1996; Peterson and Dwyner, 1998). In this context, wild edible plants can have important beneficial effects in the prevention of several modern chronic diseases, such as age- and heart-related pathologies, diabetes and cancers (Finkel and Holbrook, 2000), and the consumption of some species provides effective anti-inflammatory, abdominal, carminative, purifying, diuretic, emollient, laxative, and refreshing effects (Bianco et al., 2009). Wild, naturally growing vegetables are considered healthier than cultivated species as they should be free of chemicals, such as residues from the fertilisers and pesticides. However, if they are collected along roads with heavy vehicular traffic, they might contain toxic substances, including heavy metals (Alloway, 2004; Clark et al., 2006; Renna et al., 2014). Moreover, high nitrate contents represent a serious threat to human health, and these can be higher in cultivated vegetables than in wild plants due to the use of synthetic nitrogen fertilisers in intensive agriculture (Santamaria, 2006; Guil Guerrero et al., 1999; Ranfa et al., 2014; Schaffer et al., 2005; Vanzani et al., 2011). Despite these facts, some wild edible plants have been subjected to more-or-less suc- cessful attempts at cultivation, both in fields and protected environments and even in soilless systems (Bianco et al., 2009).

Therefore, considering the increased interest in the use of wild edible plants as food and the fact that many species have been poorly researched, the present study aims to highlight the qualitative characteristics (i.e., protein, mineral, and polyphenol contents as well as antioxidant activities) of wild herbaceous species that are traditionally consumed in southern Italy (Foggia Province) and to compare these characteristics between several wild and cultivated species.

\section{Materials and methods}

\section{Agronomic conditions and sampling procedure}

This study was conducted at the Department of Agriculture, Food and Environment of the University of Foggia, and it qualitatively analysed 11 wild edible plants that are deeply rooted in the traditional cuisine of Foggia Province: Beta vulgaris L., Foeniculum vulgare Miller, Centaurea solstitialis L., Cichorium intybus L., Scolymus hispanicus L., Sonchus oleraceus L., Borago officinalis L., Diplotaxis erucoides L., Diplotaxis tenuifolia (L.) DC, Sinapis arvensis L., and Portulaca oleracea L. In addition, cultivated plants of $C$. intybus, B. officinalis and D. tenuifolia were collected. Table 1 provides the details of each plant species including botanical family, scientific name, common English name, harvesting time, edible parts, and culinary uses.

The study plants were collected from autumn of 2015 until spring of 2016 in the Foggia countryside (Figure 1) when these wild species are most suitable for consumption. Wild species were sampled more than 200 metres from roads (buffer zone) to avoid possible contamination. Forty plants of each species were manually collected and pooled to form a single sample. The cultivated plant species, which were grown in open field according to local agronomic standards, were collected from some Apulian farms. For these species the soil was lowing to $30 \mathrm{~cm}$ depth, and before transplanting or sowing, its surface was milled. Pretransplanting/sowing fertilisation was applied to the soil by distributing $60 \mathrm{~kg} \mathrm{ha}^{-1} \mathrm{~N}$ and $30 \mathrm{~kg} \mathrm{ha}^{-1} \mathrm{P}_{2} \mathrm{O}_{5}$. C. Intybus was trans-

Table 1. Details of the wild herbaceous edible plants in this study.

\begin{tabular}{|c|c|c|c|c|c|}
\hline Family & Scientific name & CEN & Harvesting time & Edible part & Culinary use \\
\hline Amaranthaceae & Beta vulgaris $L$. & Wild beet & October to April & Leaf, stem & Boiled, salted rustic cakes, soups \\
\hline Apiaceae & Foeniculum vulgare $M$. & Wild fennel & $\begin{array}{c}\text { Leaves in Spring, stems L } \\
\text { and seeds in Summer-Autumn }\end{array}$ & Leaf, fresh seed, dry seed & $\begin{array}{l}\text { Boiled, seasoning, salads, pickles or } \\
\text { pickled, soups }\end{array}$ \\
\hline Asteraceae & $\begin{array}{l}\text { Centaurea solstitialis L. } \\
\text { Cichorium intybus L.* } \\
\text { Scolymus hispanicus L. } \\
\text { Sonchus oleraceus L. }\end{array}$ & $\begin{array}{l}\text { Yellow cornflower } \\
\text { Wild chicory } \\
\text { Common cardogna } \\
\text { Sow thistles }\end{array}$ & $\begin{array}{c}\text { April to June } \\
\text { October to April } \\
\text { December to May } \\
\text { Throughout the year; best in spring }\end{array}$ & $\begin{array}{c}\text { Leaf, root } \\
\text { Root, flower, leaf } \\
\text { Flower, rib leaf, root } \\
\text { g Leaf, seed, flower }\end{array}$ & $\begin{array}{l}\text { Oil, salad } \\
\text { Boiled, salads, rustic pies, soups } \\
\text { Boiled, soups } \\
\text { Boiled, salads, rustic pies, soups }\end{array}$ \\
\hline Boraginaceae & Borago officinalis L.* & Starflower & October to June & Leaf, flower & $\begin{array}{l}\text { Boiled, omelettes, salads, salted, } \\
\text { rustic cakes, soups }\end{array}$ \\
\hline \multirow[t]{2}{*}{ Brassicaceae } & $\begin{array}{l}\text { Diplotaxis erucoides (L.) DC } \\
\text { Diplotaxis tenuifolia } \text { L.* }^{*}\end{array}$ & $\begin{array}{l}\text { Purplish rocket } \\
\text { Wild rocket }\end{array}$ & $\begin{array}{l}\text { September to March } \\
\text { Throughout the year }\end{array}$ & $\begin{array}{l}\text { Leaf } \\
\text { Leaf }\end{array}$ & $\begin{array}{l}\text { Boiled, salads, rustic pies, } \\
\text { Boiled, salads, seasoning, } \\
\text { savoury or rustic cakes }\end{array}$ \\
\hline & Sinapis arvensis L. & Wild mustard & March to June & Leaf, flower & $\begin{array}{l}\text { Boiled, salads, seasoning, } \\
\text { savoury or rustic cakes }\end{array}$ \\
\hline Portulacaceae & Portulaca oleracea L. & Purslane & June to September & Leaf & $\begin{array}{l}\text { Boiled, salads, omelettes, pickles } \\
\text { or pickled, and soups }\end{array}$ \\
\hline
\end{tabular}

CEN, common English name. *Both wild and cultivated plants of these species were analysed. 
planted on October $8^{\text {th }}, 2015\left(10\right.$ plant $\left.\mathrm{m}^{-2}\right)$ and harvested on February $22^{\text {th }}, 2016 ; B$. Officinalis was directly sown in the field on April $10^{\text {th }} 2016$ (16.7 plant $\mathrm{m}^{-2}$ ) and harvested on June $20^{\text {th }}$, 2016; D.tenuifolia was sown on April 5 $5^{\text {th }}, 2016$ (66.7 plant $\mathrm{m}^{-2}$ ) and harvested on June $30^{\text {th }}, 2016$. For all cultivated specie the pest and weed control were performed according to local management practices. Drip irrigation system was used for their irrigation. This method comprised a single pipe, with drippers at a $2 \mathrm{~L} \mathrm{~h}^{-1}$ flow rate. The amount of irrigation water applied to $C$. Intybus, $B$. Officinalis and D.tenuifolia during the whole crop cycles was 1400,1500 and $1700 \mathrm{~m}^{3} \mathrm{ha}^{-1}$, respectively.

All sample plants were transported to the laboratory under refrigerated conditions for analysis. Fifty-six samples (four replicates of 11 wild and three cultivated species) were gently cleaned and separated into edible and waste parts, which included the older leaves and stems that are normally removed during preparation for cooking.

\section{Qualitative analysis}

For each sample, four replicates of the edible parts were analysed for dry matter, protein, cations and anions. Total polyphenols and antioxidant activity were also determined.

To measure dry matter, samples of the edible fresh portions of the plants were dried to a constant weight in a forced-air oven at $65^{\circ} \mathrm{C}$, and these data are expressed as $\mathrm{g}$ per $100 \mathrm{~g}$ fresh weight (Fw). Total nitrogen was determined using a LECO CHN-600 determinator, and protein content was calculated by multiplying the total nitrogen by 6.25 and is expressed as g per $100 \mathrm{~g} \mathrm{Fw}$.

The anion (fluoride, chloride, nitrate, phosphate and sulfate) and cation (sodium, potassium, magnesium, calcium) contents were determined using ion-exchange chromatography (ICS-1100; Dionex Corporation, Sunnyvale, CA, USA). The anions were extracted from 0.5 -g dried and ground samples with $50 \mathrm{~mL} 3.5$ nmol L ${ }^{-1} \mathrm{NaCO}_{3}$ and $1.0 \mathrm{mmol} \mathrm{L}{ }^{-1} \mathrm{NaHCO}_{3}$, and the extracts were analysed using a guard column and an analytical column (Ionpac AG14 and AS14, respectively). The data are expressed as $\mathrm{mg} \mathrm{kg}^{-1}$ Fw. For the cations, 1.0-g dried and ground samples were used with the ash produced in a muffle furnace at $550{ }^{\circ} \mathrm{C}$ that was then digested in $20 \mathrm{~mL} 1.0 \mathrm{~mol} \mathrm{~L}^{-1} \mathrm{HCl}$ in boiling water $\left(99.5 \pm 0.5^{\circ} \mathrm{C}\right)$ for $30 \mathrm{~min}$. The resulting solution was filtered, diluted, and analysed using a guard column and analytical column (Ionpac CG12A and CS12A, respectively). The data are expressed as $\mathrm{mg} \mathrm{kg}^{-1} \mathrm{FW}$ (Renna et al., 2014).

The total phenol content was determined according to the method of Singleton and Rossi (1965) and expressed as mg gallic acid equivalents (GAE) per kg Fw. The antioxidant activity of the plant extracts was determined by the method of Brand-Williams et al. (1995) with modifications. The diluted samples $(50 \mu \mathrm{L})$ were added to $950 \mu \mathrm{L}$ 1,1-diphenyl-2-picrylhydrazyl (DPPH) solution to initiate the reactions, and after incubation overnight at $23^{\circ} \mathrm{C}$, the absorbance was read using a spectrophotometer (Perkin Elmer UV/VIS LAMBDA 45) at $515 \mathrm{~nm}$. Trolox was used as the standard for analysis, and the antioxidant activity is reported as mg Trolox equivalents (TE) per kg Fw.

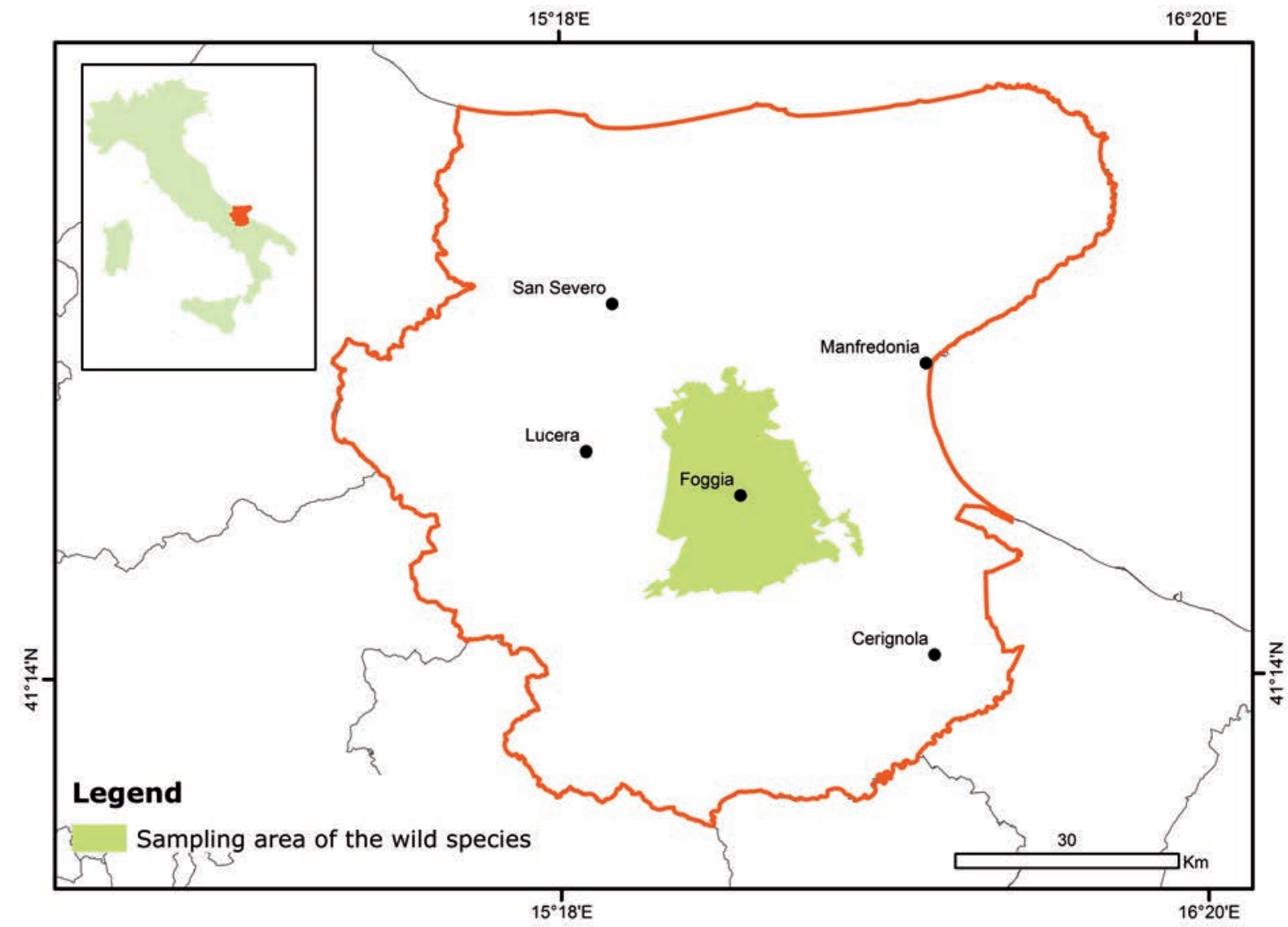

Figure 1. Map of Italy showing the location of Foggia Province. 


\section{Statistical analysis}

The datasets were analysed according to the basic assumptions for analysis of variance (ANOVA). The normality of the distributions and the common variance of the experimental error were verified by Shapiro-Wilk and Bartlett's tests, respectively. When required, Box-Cox transformations (Box and Cox, 1964) were applied prior to analysis, and for all data, the ANOVA was performed according to a completely randomised design with four replicates. The differences between the means were determined by Tukey's honest significance difference post hoc tests at the 5\% probability level, and bivariate statistical methods were applied (linear regression analysis) to determine the relationships between the different qualitative characteristics of the herbaceous food plants.

Furthermore, the qualitative parameters of the wild edible plants were jointly considered using a multivariate approach. Cluster analysis (Everitt, 1980; Aldenderfer and Blashfiel, 1984) was used to find truly homogeneous groups of species. Ward's minimum variance hierarchical clustering was performed using an agglomerative approach and Ward's linkage, and at each cluster definition, samples were added into superior clusters to minimise the within-cluster sum of squares or maximise the between-cluster sum of squares (Podani, 2007; Moore et al., 2010). To compare differences among clusters, ANOVA and Tukey's tests were used for all continuous variables (5\% probability level).

Linear discriminant analysis (Moore et al., 2010; McLaclan, 1992; Webb, 2002; Cammareri et al., 2004) was used to best explain the differences between the different cluster groups obtained by cluster analysis and to evaluate which of the main parameters play the most important roles in determining these differences. The independent variables defined 13 qualitative parameters, and the dependent variable was the wild species. The first two linear discriminant canonicals $\left(\mathrm{CN}_{\mathrm{s}}\right)$ accounted for the largest portion of the variability in the data and were considered for data interpretation. The selected $\mathrm{CN}_{\mathrm{s}}$ were graphically represented in biplots, in which the discriminant scores were plotted as symbols, and the standardised coefficients for each of the original variables were reported as vectors and used to interpret the data. Before the cluster and linear discriminant analyses, the values of each parameter were correctly standardised.

The ANOVA, cluster analysis and linear discriminant analysis were performed using the JMP software package, version 8.1 (SAS Institute Inc., Cary, NC, USA), and graphs were constructed using SigmaPlot (Systat Software, Chicago, IL, USA).

\section{Results}

\section{Qualitative characteristics of wild herbaceous food plants}

Figures 2-5 show the means, standard errors, and significance of the analysed qualitative parameters for the edible parts of each wild edible plant species. All of the considered parameters differed significantly among the species.

Dry matter content in the tested plants ranged from $7.1 \mathrm{~g} 100$

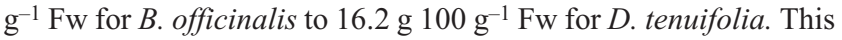
highest mean value was not significantly different from the means for $F$. vulgare and $C$. solstitialis. The values for these species were followed by those for $S$. arvensis (12.3 mg per $100 \mathrm{~g} \mathrm{Fw}$ ) and $D$. erucoides (10.4 mg per $100 \mathrm{~g} \mathrm{Fw}$ ), and the means were significant- ly lower for all the other species (Figure 2A).

The mean protein content ranged from $1.9 \mathrm{mg} 100 \mathrm{~g}^{-1} \mathrm{FW}$ for C. intybus to $4.8 \mathrm{mg} 100 \mathrm{~g}^{-1} \mathrm{FW}$ for $D$. tenuifolia, but this high value was not significantly different from the protein content of $F$. vulgare, $S$. arvensis, D. euricoides, and $C$. solstitialis. These wild species appeared to have very high protein levels with respect to common vegetables (lettuce, spinach, parsley, carrots and cabbage) (McCollum, 1992; Singh et al., 2001). All the other species showed low values (never less than $2 \mathrm{mg} 100 \mathrm{~g}^{-1} \mathrm{Fw}$ ) that were not significantly different from each other (Figure $2 \mathrm{~B}$ ).

The mean values of the minerals (i.e., sodium, potassium, magnesium and calcium) that are important for human nutrition are reported in Figure 3; generally, the differences between the minimum and maximum values for the analysed species were approximately 3-fold for potassium and approximately 7-8-fold for magnesium, calcium, and sodium. The highest sodium content was $2992 \mathrm{mg} \mathrm{kg}^{-1} \mathrm{Fw}$ for B. vulgaris, which was significantly higher than that for all the other species for which the means ranged from $357 \mathrm{mg} \mathrm{kg}^{-1} \mathrm{Fw}$ for $D$. euricoides to $802 \mathrm{mg} \mathrm{kg}^{-1} \mathrm{Fw}$ for $D$. tenuifolia but were not significant different (Figure 3A).

The potassium levels ranged from $1870 \mathrm{mg} \mathrm{kg}^{-1} \mathrm{FW}$ for $P$. oleracea to $6090 \mathrm{mg} \mathrm{kg}^{-1} \mathrm{Fw}$ for $S$. hispanicus, which showed a value
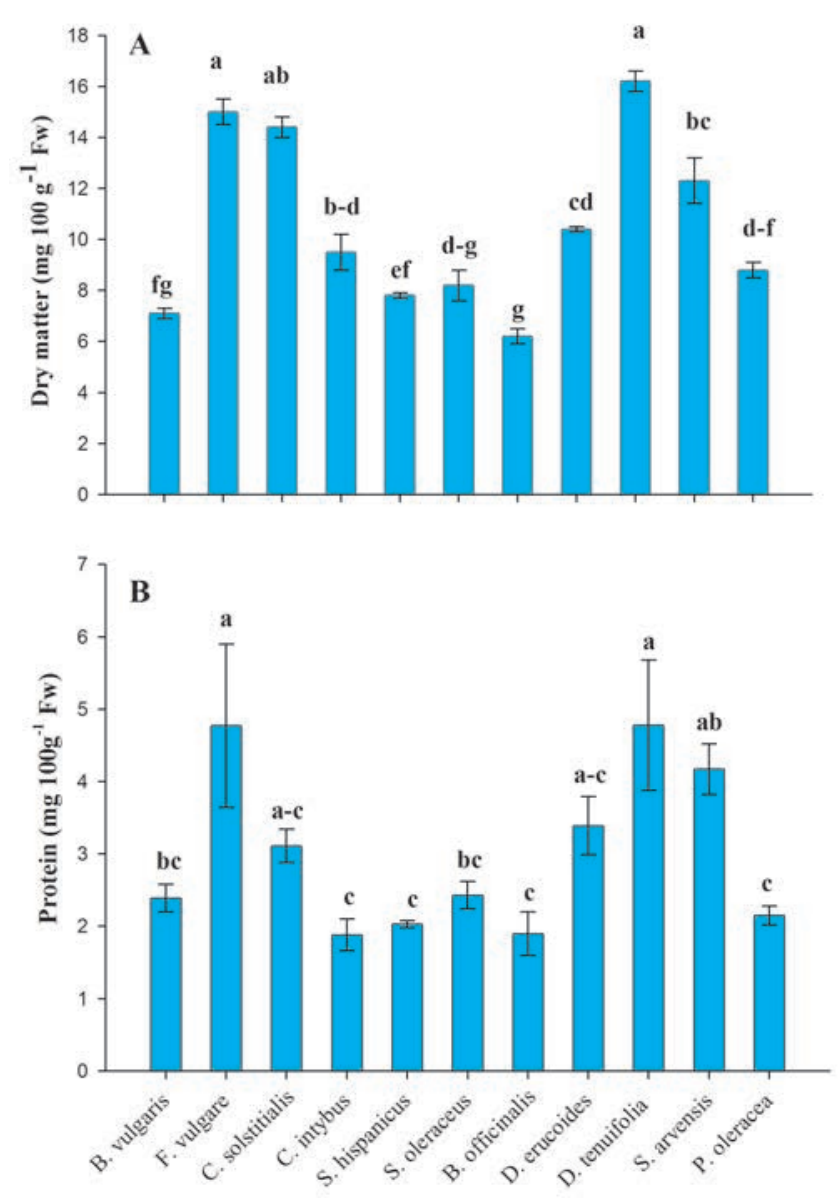

Figure 2. Mean dry matter (A) and protein contents (B) in the fresh samples of the 11 wild edible plant species in the study. Data are means \pm standard errors for each analysed parameter as determined from 4 samples (replicates). Means followed by different letters are significantly different $(P=0.05$; Tukey's test). 
similar to that of D. tenuifolia and B. officinalis followed by F. vulgare and $C$. intybus. All the other species showed significantly lower potassium levels $\left(<4000 \mathrm{mg} \mathrm{kg}^{-1} \mathrm{Fw}\right)$ with no significant differences among them (Figure 3B).

The magnesium levels ranged from $79 \mathrm{mg} \mathrm{kg}^{-1} \mathrm{FW}$ for $B$. vulgaris to $646 \mathrm{mg} \mathrm{kg}^{-1} \mathrm{Fw}$ for $S$. hispanicus, but the high magnesium value for $S$. hispanicus was not significantly different from that of D. tenuifolia, which was not significantly different from that of $C$. solstitialis. All the other species showed lower magnesium contents from 259 to $385 \mathrm{mg} \mathrm{kg}^{-1} \mathrm{FW}$, with no significant differences among them (Figure 3C).

Calcium levels were highest for $S$. hispanicus (5886 $\mathrm{mg} \mathrm{kg}^{-1}$ Fw) and significantly differed from those of all the other species. The lowest calcium content was $784 \mathrm{mg} \mathrm{kg}^{-1} \mathrm{Fw}$ for B. vulgaris, although this value was not significantly different from that of $P$. oleracea, S. oleraceus, B. officinalis, $C$. intybus, and cultivated $B$. officinalis. The other species showed intermediate calcium levels from 2550 to $3750 \mathrm{mg} \mathrm{kg}^{-1} \mathrm{Fw}$ (Figure 3D). The differences between the minimum and maximum anion contents (i.e., nitrates, fluorides, chlorides, phosphorus and sulfur; Figure 4A-C) of these different species ranged from approximately 11-12-fold for fluorides, chlorides and sulfur to approximately 50 -fold for nitrates to the greatest difference of approximately 137 -fold for phosphorus.

The nitrate contents ranged from $75 \mathrm{mg} \mathrm{kg}^{-1} \mathrm{Fw}$ for wild $C$. intybus to $3874 \mathrm{mg} \mathrm{kg}^{-1} \mathrm{Fw}$ for $D$. tenuifolia, which was not significantly different from that of $C$. solstitialis (3579 $\mathrm{mg} \mathrm{kg}^{-1} \mathrm{Fw}$ ) that, in turn, was not significantly different from that of $S$. arvensis (3028 $\mathrm{mg} \mathrm{kg}^{-1} \mathrm{Fw}$ ) followed by D. erucoides (2024 $\left.\mathrm{mg} \mathrm{kg}^{-1} \mathrm{Fw}\right)$.

The highest fluoride levels were found in D. tenuifolia $(180 \mathrm{mg}$ $\mathrm{kg}^{-1} \mathrm{Fw}$ ), which differed significantly from all the other species. The values ranged from $16 \mathrm{mg} \mathrm{kg}^{-1} \mathrm{Fw}$ for $P$. oleracea to $126 \mathrm{mg}$ $\mathrm{kg}^{-1} \mathrm{Fw}$ for $C$. intybus, which was not significantly different from $F$. vulgare. The other species showed low fluoride levels ranging from 16 to $69 \mathrm{mg} \mathrm{kg}^{-1} \mathrm{Fw}$.

The highest level of chlorides was $9348 \mathrm{mg} \mathrm{kg}^{-1} \mathrm{Fw}$ for $C$. solstitialis, which differed significantly from all of the other species, whose values ranged from $832 \mathrm{mg} \mathrm{kg}^{-1} \mathrm{Fw}$ for $S$. arvensis to 3070 $\mathrm{mg} \mathrm{kg}^{-1} \mathrm{Fw}$ for F. vulgare. In turn, the value of the latter was not significantly different from that of $S$. hispanicus followed by all of the other species whose lower values were not significantly different.

The phosphorus levels were significantly higher in C. intybus (511 $\mathrm{mg} \mathrm{kg}^{-1} \mathrm{Fw}$ ) although they were not significantly different from those of $S$. arvensis $\left(437 \mathrm{mg} \mathrm{kg}^{-1} \mathrm{Fw}\right)$ and $C$. solstitialis $(406$ $\mathrm{mg} \mathrm{kg}^{-1} \mathrm{Fw}$ ). All the other species showed levels ranging from 4 $\mathrm{mg} \mathrm{kg}^{-1} \mathrm{Fw}$ for $F$. vulgare to $179 \mathrm{mg} \mathrm{kg}^{-1} \mathrm{Fw}$ for D. tenuifolia.

Finally, the highest sulfur level of $741 \mathrm{mg} \mathrm{kg}^{-1} \mathrm{Fw}$ was seen in S. arvensis, although this value was not significantly different from
A
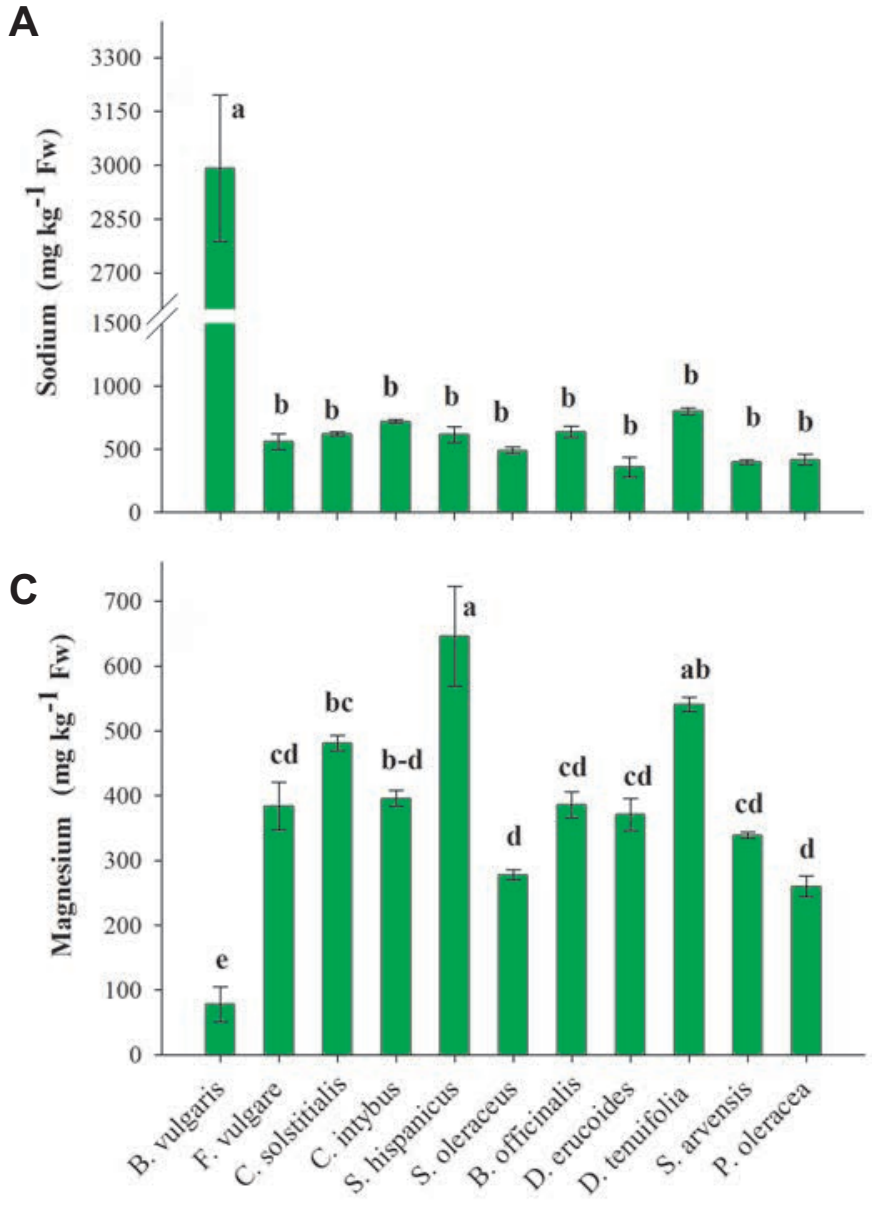

B
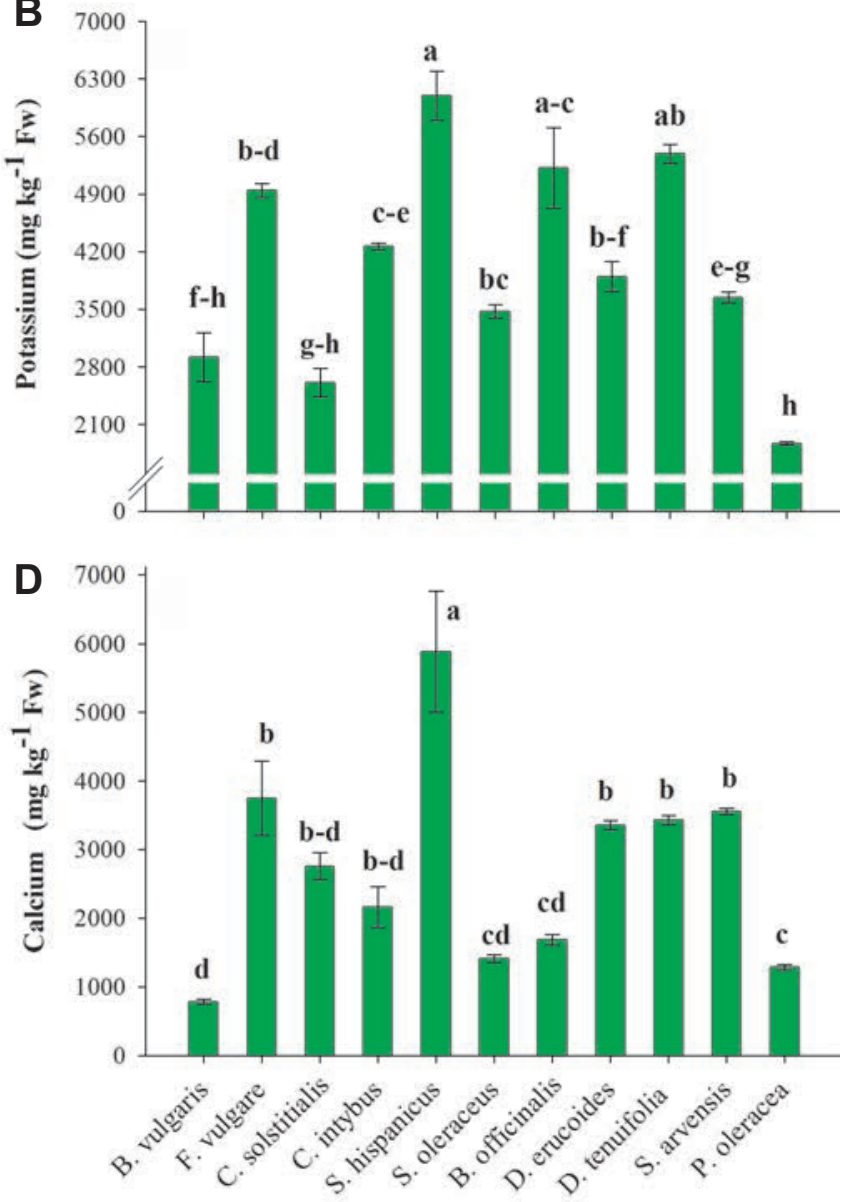

Figure 3. Mean cation contents in the fresh samples of the 11 wild edible plant species in the study: sodium (A), potassium (B), magnesium (C) and calcium (D). Data are means \pm standard errors for each analysed parameter as determined from 4 samples (replicates). Means followed by different letters are significantly different ( $P=0.05$; Tukey's test). 
$645 \mathrm{mg} \mathrm{kg}^{-1} \mathrm{Fw}$ for $P$. oleracea and $616 \mathrm{mg} \mathrm{kg}^{-1} \mathrm{Fw}$ for $F$. vulgare. The levels of these two species were not significantly different from the value of $543 \mathrm{mg} \mathrm{kg}^{-1} \mathrm{FW}$ for D. tenuifolia, which was followed by the intermediate levels of $399.3 \mathrm{mg} \mathrm{kg}^{-1} \mathrm{Fw}$ for $S$. hispanicus and $358 \mathrm{mg} \mathrm{kg}^{-1} \mathrm{Fw}$ for $C$. intybus.

The total polyphenol content of the analysed plants ranged from $1054 \mathrm{mg} \mathrm{GAE} \mathrm{kg}^{-1} \mathrm{Fw}$ for C. solstitialis to $3664 \mathrm{mg} \mathrm{GAE} \mathrm{kg}^{-}$ ${ }^{1} \mathrm{Fw}$ for $S$. arvensis, which was not significantly different from the total polyphenols for wild $C$. intybus (3073 $\mathrm{mg} \mathrm{GAE} \mathrm{kg}^{-1} \mathrm{Fw}$ ), $B$. officinalis (2728 mg GAE kg-1 Fw) and $S$. hispanicus $(2586 \mathrm{mg}$ $\mathrm{GAE} \mathrm{kg}^{-1} \mathrm{Fw}$ ). The value for this last species was followed by those for $S$. oleraceus and $D$. erucoides. The low total polyphenol contents for the remaining species ranged from 1054 to $1639 \mathrm{mg}$ GAE kg-1 Fw (Figure 5A).

There were large variations in antioxidant activities that ranged from $839 \mathrm{mg} \mathrm{TE} \mathrm{kg}^{-1} \mathrm{Fw}$ for B. vulgaris to $5658 \mathrm{mg} \mathrm{TE} \mathrm{kg}^{-1} \mathrm{FW}$ for $C$. intybus, whose value was significantly different from those of the other species. This activity level was followed by those of $B$. officinalis (3928 mg TE kg-1 Fw), D. erucoides (3920 mg TE kg-1 $\mathrm{Fw})$, S. arvensis (3669 $\left.\mathrm{mg} \mathrm{TE} \mathrm{kg}^{-1} \mathrm{Fw}\right)$, and S. hispanicus (2719 $\mathrm{mg}$ TE $\mathrm{kg}^{-1} \mathrm{Fw}$ ), which were not significantly different from each other, and low values of $<2151 \mathrm{mg} \mathrm{TE} \mathrm{kg} \mathrm{gw}^{-1} \mathrm{FW}$ were observed for the other species (Figure 5B).

\section{Qualitative characteristics of wild $v$ s cultivated herba- ceous edible plants}

The qualitative characteristics of three wild and cultivated species, C. intybus, B. officinalis, and D. tenuifolia, were also compared. Table 2 shows the means, standard errors, and significance values of these parameters for the edible parts of each species.

Dry matter contents of these three species did not differ between the wild and cultivated plants, and the same was observed for the protein content.

Sodium levels were significantly higher in cultivated $C$. intybus (902 $\mathrm{mg} \mathrm{kg}^{-1} \mathrm{Fw}$ ) compared to wild C. intybus (720.2 $\mathrm{mg} \mathrm{kg}^{-1} \mathrm{Fw}$ ). In contrast, wild $D$. tenuifolia showed significantly higher sodium levels than cultivated $D$. tenuifolia, and the same pattern was seen for potassium levels. No differences in potassium levels were observed between the wild and cultivated C. intybus and B. officinalis plants.

The magnesium and calcium levels also showed no differences between these three wild and cultivated species. The fluoride content did not differ between the wild and cultivated $C$. intybus and B. officinalis, while they were significantly higher in wild $(180 \mathrm{mg}$ $\mathrm{kg}^{-1} \mathrm{Fw}$ ) than in cultivated $D$. tenuifolia $\left(117 \mathrm{mg} \mathrm{kg}^{-1} \mathrm{Fw}\right)$. The chloride levels were significantly higher in cultivated $C$. intybus (3740 mg kg-1 Fw) than wild plants (1807 mg kg-1 Fw), whereas no differences were observed between both wild and cultivated $B$. officinalis and D. tenuifolia. The phosphorus levels in $C$. intybus and $B$. officinalis did not differ between wild and cultivated plants, but cultivated $D$. tenuifolia showed significantly higher phosphorus levels $\left(562.5 \mathrm{mg} \mathrm{kg}^{-1} \mathrm{Fw}\right)$ than the wild plants $\left(178.7 \mathrm{mg} \mathrm{kg}^{-1}\right.$ Fw). The same was observed for sulfur levels, which did not differ between wild and cultivated $C$. intybus and B. officinalis, while significantly higher levels were seen in cultivated $D$. tenuifolia (863.5 $\left.\mathrm{mg} \mathrm{kg}^{-1} \mathrm{Fw}\right)$ relative to wild plants $\left(741.5 \mathrm{mg} \mathrm{kg}^{-1} \mathrm{Fw}\right)$.

The nitrate contents of the wild C. intybus, B. officinalis and D. tenuifolia were significantly lower $(75.5 ; 1060.7$ and $3873.9 \mathrm{mg}$ $\mathrm{kg}^{-1} \mathrm{FW}$, respectively) compared to those of cultivated plants (2191.8; 1438 and 4853,5 $\mathrm{mg} \mathrm{kg}^{-1} \mathrm{FW}$, respectively).

Only considering these three species, the total polyphenols and antioxidant activity were significantly highest in C. intybus (2688
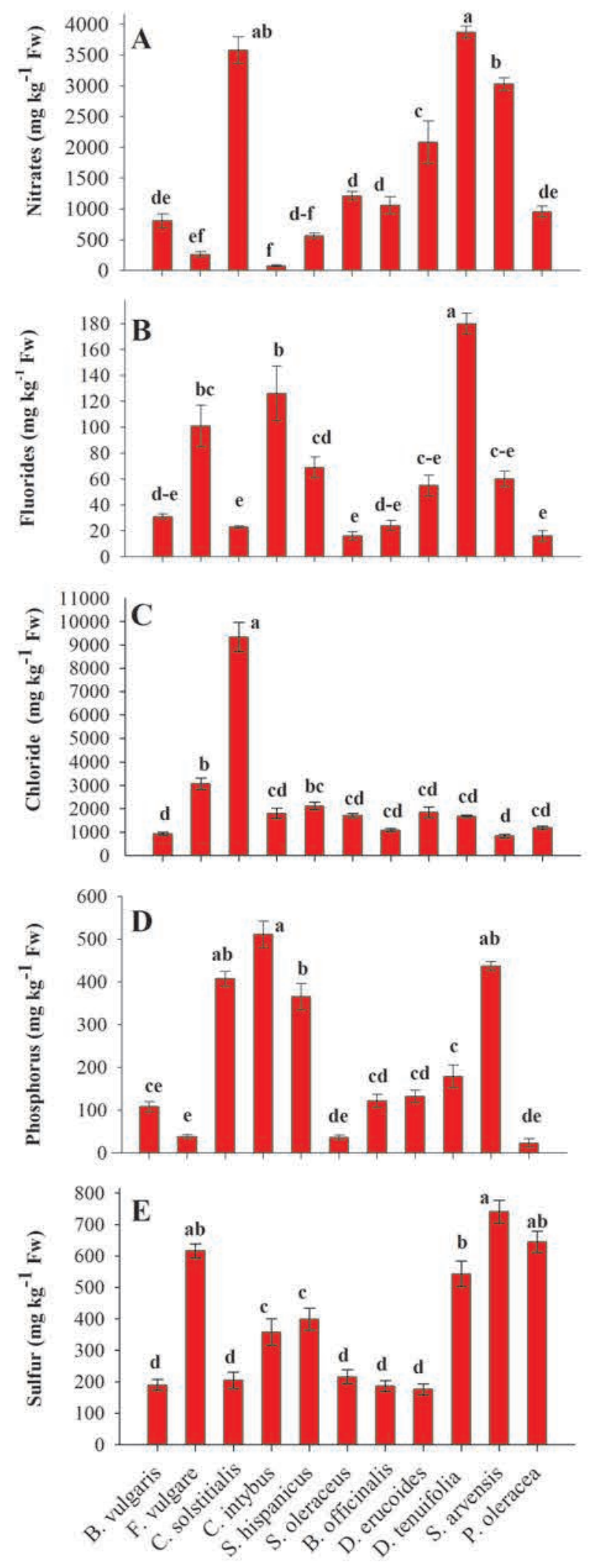

Figure 4. Mean anion contents in the fresh samples of the 11 wild edible plant species in the study: fluoride (A), chloride (B), nitrates (C), phosphorus (D), and sulphur (E). Data are means \pm standard errors for each analysed parameter as determined from 4 samples (replicates). Means followed by different letters are significantly different $(P=0.05$; Tukey's test). 
mg GAE kg ${ }^{-1} \mathrm{Fw}$ and $4111 \mathrm{mg} \mathrm{TE} \mathrm{g}^{-1} \mathrm{Fw}$, respectively) followed by $B$. officinalis (2333 $\mathrm{mg} \mathrm{GAE} \mathrm{kg}^{-1} \mathrm{Fw}$ and $3141 \mathrm{mg} \mathrm{TE} \mathrm{kg}^{-1} \mathrm{Fw}$, respectively) and D. tenuifolia (1558 $\mathrm{mg} \mathrm{GAE} \mathrm{kg}^{-1} \mathrm{FW}$ and 1357 $\mathrm{mg} \mathrm{TE} \mathrm{kg}{ }^{-1} \mathrm{Fw}$, respectively). Moreover, the total polyphenols and antioxidant activities were significantly higher in the wild plants compared to the cultivated plants for both C. intybus and B. officinalis, but there were no differences between wild and cultivated $D$. tenuifolia (Table 2). Finally, there was a positive and highly significant linear correlation between the total polyphenol contents and antioxidant activities of all of the analysed species (Figure 6).

\section{Cluster and linear discriminant analysis results}

The cluster analysis of all the qualitative characteristics of the 11 herbaceous species identified five clusters (Figure 7). The best number of clusters was defined through the inverse relationship between the number of clusters and the mean distances among them. Thus, an increase in the number of clusters did not result in any substantial reduction in the distances between the clusters. As a result of this analysis, the mean of each qualitative parameter ( \pm standard error) as well as the significance level (P-value) of the ANOVA for each variable were represented by each cluster (Table $3)$. Significant differences among the variables were based on $\mathrm{P} \leq 0.05$.

Cluster 1 comprises B. vulgaris and P. oleracea and is characterised by very low values for all the qualitative parameters considered except for the sodium level. Cluster 2 comprises $C$. intybus, $S$. hispanicus and $S$. arvensis, all of which show high antioxidant activity and total phenol, potassium and calcium contents. Cluster 3 comprises the two wild species of $F$. vulgare and D. tenuifolia, and it is distinguished by higher dry matter, fluoride, potassium, and sulfate contents than the other clusters. Cluster 4 contains a single species, $C$. solstitialis, and it is primarily characterised by

Table 2. Comparisons between the three analysed wild and cultivated species.

\begin{tabular}{|c|c|c|c|c|c|c|c|c|c|c|}
\hline \multirow[t]{2}{*}{ Parameter } & \multirow[t]{2}{*}{ Units } & \multicolumn{3}{|c|}{ Cichorium intybus L. } & \multicolumn{3}{|c|}{ Borago officinalis L. } & \multicolumn{3}{|c|}{ Diplotaxis tenuifolia L. } \\
\hline & & Wild & Cultivated & $\mathbf{P}$ & Wild & Cultivated & $\mathbf{P}$ & Wild & Cultivated & $\mathbf{P}$ \\
\hline Dry matter & $\mathrm{mg} 100 \mathrm{~g}^{-1} \mathrm{Fw}$ & $9.45 \pm 0.70$ & $14.0 \pm 0.12$ & ns & $6.18 \pm 0.15$ & $8.13 \pm 0.38$ & ns & $16.20 \pm 0.51$ & $9.68 \pm 0.29$ & ns \\
\hline Protein & $\mathrm{mg} 100 \mathrm{~g}^{-1} \mathrm{Fw}$ & $1.88 \pm 0.22$ & $2.94 \pm 0.28$ & ns & $1.90 \pm 0.10$ & $2.27 \pm 0.07$ & ns & $4.78 \pm 0.14$ & $2.75 \pm 0.10$ & ns \\
\hline Sodium & $\mathrm{mg} \mathrm{kg}^{-1} \mathrm{Fw}$ & $720.2 \pm 15.8$ & $901.8 \pm 52.4$ & * & $637.1 \pm 45.8$ & $524.0 \pm 51.3$ & ns & $802.3 \pm 19.4$ & $282.5 \pm 25.6$ & $*$ \\
\hline Potassium & $\mathrm{mg} \mathrm{kg}^{-1} \mathrm{Fw}$ & $4264.2 \pm 39.6$ & $4998.2 \pm 89.5$ & ns & $5219.4 \pm 489.7$ & $4385.5 \pm 253.0$ & ns & $5391.4 \pm 82.5$ & $3264.3 \pm 327.1$ & $*$ \\
\hline Magnesium & $\mathrm{mg} \mathrm{kg}^{-1} \mathrm{FW}$ & $395.5 \pm 11.6$ & $439.5 \pm 28.0$ & ns & $385.5 \pm 20.4$ & $295.5 \pm 34.3$ & ns & $541.0 \pm 10.8$ & $428.8 \pm 33.6$ & ns \\
\hline Calcium & $\mathrm{mg} \mathrm{kg}^{-1} \mathrm{Fw}$ & $2160.8 \pm 296.9$ & $2671.8 \pm 226.5$ & ns & $1686.4 \pm 76.3$ & $2424.8 \pm 262.4$ & ns & $2551.0 \pm 40.1$ & $2789.8 \pm 118.7$ & ns \\
\hline Fluorides & $\mathrm{mg} \mathrm{kg}^{-1} \mathrm{FW}$ & $125.8 \pm 20.8$ & $76.1 \pm 7.2$ & ns & $24.5 \pm 4.1$ & $41.3 \pm 7.7$ & ns & $180.1 \pm 5.9$ & $117.5 \pm 13.8$ & $*$ \\
\hline Chlorides & $\mathrm{mg} \mathrm{kg}^{-1} \mathrm{Fw}$ & $1807.1 \pm 218.2$ & $3740.3 \pm 377.0$ & $*$ & $1087.0 \pm 71.3$ & $2021.3 \pm 234.2$ & ns & $1682.0 \pm 38.1$ & $1358.0 \pm 97.5$ & ns \\
\hline Nitrates & $\mathrm{mg} \mathrm{kg}^{-1} \mathrm{Fw}$ & $75.5 \pm 14.7$ & $2191.8 \pm 184.4$ & $*$ & $1060.7 \pm 137.9$ & $1438.3 \pm 108.6$ & $*$ & $3873.9 \pm 68.0$ & $4853.5 \pm 119.2$ & $*$ \\
\hline Phosphorus & $\mathrm{mg} \mathrm{kg}^{-1} \mathrm{Fw}$ & $511.2 \pm 31.5$ & $498.5 \pm 63.2$ & ns & $131.8 \pm 14.4$ & $121.5 \pm 5.2$ & ns & $178.7 \pm 10.9$ & $562.5 \pm 56.2$ & $*$ \\
\hline Sulfur & $\mathrm{mg} \mathrm{kg}^{-1} \mathrm{FW}$ & $399.3 \pm 35.1$ & $358.3 \pm 41.8$ & ns & $176.3 \pm 17.3$ & $186.8 \pm 17.0$ & ns & $741.5 \pm 6.4$ & $863.5 \pm 21.9$ & $*$ \\
\hline Total phenols & mg GAE $\mathrm{kg}^{-1} \mathrm{Fw}$ & $3072.6 \pm 123.9$ & $2302.8 \pm 103.5$ & $*$ & $2728.0 \pm 239.6$ & $1938.5 \pm 93.6$ & $*$ & $1699.0 \pm 86.3$ & $1477.0 \pm 84.0$ & ns \\
\hline Antioxidant activity & $\mathrm{mg} \mathrm{TE} \mathrm{kg}{ }^{-1} \mathrm{FW}$ & $5658.2 \pm 67.4$ & $2563.2 \pm 124.1$ & $*$ & $3928.1 \pm 93.1$ & $2362.7 \pm 51.0$ & $*$ & $1340.8 \pm 147.6$ & $1373.8 \pm 127.8$ & ns \\
\hline
\end{tabular}

Fw, fresh weight; GAE, gallic acid equivalents; TE, Trolox equivalents. Values are means \pm standard errors for each analysed parameter as determined from 4 samples (replicates). *Fisher's test value significant at $\mathrm{P} \leq 0.05$; ns, not significant $(\mathrm{P}>0.05)$.

Table 3. Results of the analysis of variance of all qualitative parameters for the different clusters.

\begin{tabular}{|c|c|c|c|c|c|c|}
\hline Parameter & Units & $\begin{array}{c}\text { Cluster } 1 \\
\quad(n=8)\end{array}$ & $\begin{array}{c}\text { Cluster } 2 \\
(n=12)\end{array}$ & $\begin{array}{c}\text { Cluster } 3 \\
(n=8)\end{array}$ & $\begin{array}{c}\text { Cluster } 4 \\
(n=12)\end{array}$ & $\begin{array}{c}\text { Cluster } 5 \\
(n=3)\end{array}$ \\
\hline Dry matter & $\mathrm{mg} 100 \mathrm{~g}^{-1} \mathrm{Fw}$ & $7.94 \pm 0.37^{\mathrm{b}}$ & $9.86 \pm 0.65^{b}$ & $15.59 \pm 0.40^{\mathrm{a}}$ & $14.43 \pm 0.22^{\mathrm{a}}$ & $8.27 \pm 1.12^{\mathrm{b}}$ \\
\hline Protein & $\mathrm{mg} 100 \mathrm{~g}^{-1} \mathrm{Fw}$ & $2.2 \pm 0.11^{b}$ & $2.69 \pm 0.34^{b}$ & $4.77 \pm 0.53^{\mathrm{a}}$ & $3.11 \pm 0.13^{\mathrm{ab}}$ & $2.57 \pm 0.40^{\mathrm{b}}$ \\
\hline Sodium & $\mathrm{mg} \mathrm{kg^{-1 }} \mathrm{FW}$ & $1705.1 \pm 496.0^{\mathrm{a}}$ & $839.0 \pm 243.4^{\mathrm{ab}}$ & $681.3 \pm 54.9 \mathrm{ab}$ & $621.3 \pm 9.8^{\mathrm{ab}}$ & $494.4 \pm 89.8^{b}$ \\
\hline Potassium & $\mathrm{mg} \mathrm{kg}^{-1} \mathrm{Fw}$ & $2395.7 \pm 241.6^{b}$ & $4667 \pm 327.1^{\mathrm{a}}$ & $5168.3 \pm 100.2^{\mathrm{a}}$ & $2610.0 \pm 101.1^{b}$ & $4198.2 \pm 550.0^{\mathrm{a}}$ \\
\hline Magnesium & $\mathrm{mg} \mathrm{kg}^{-1} \mathrm{Fw}$ & $169.1 \pm 37.2^{b}$ & $459.9 \pm 46.7^{\mathrm{a}}$ & $462.3 \pm 34.6^{\mathrm{a}}$ & $482.3 \pm 7.5^{\mathrm{a}}$ & $345.2 \pm 34.9^{\mathrm{a}}$ \\
\hline Calcium & $\mathrm{mg} \mathrm{kg}^{-1} \mathrm{Fw}$ & $1034.5 \pm 98.6^{c}$ & $3867.9 \pm 542.3^{\mathrm{a}}$ & $3150.5 \pm 339.4^{\mathrm{ab}}$ & $2758.0 \pm 113.1^{\mathrm{abc}}$ & $2150.5 \pm 521.8^{b c}$ \\
\hline Fluorides & $\mathrm{mg} \mathrm{kg}^{-1} \mathrm{Fw}$ & $23.2 \pm 3.0^{c}$ & $85.0 \pm 11.3^{b}$ & $140.6 \pm 16.8^{\mathrm{a}}$ & $23.0 \pm 0.8^{c}$ & $31.8 \pm 11.6^{c}$ \\
\hline Chlorides & $\mathrm{mg} \mathrm{kg}^{-1} \mathrm{Fw}$ & $1059.6 \pm 64.6^{\mathrm{c}}$ & $1585.4 \pm 184.7^{\mathrm{bc}}$ & $2376.1 \pm 286.4^{b}$ & $9348.0 \pm 361.8^{a}$ & $1549.0 \pm 254.2^{\mathrm{bc}}$ \\
\hline Nitrates & $\mathrm{mg} \mathrm{kg}^{-1} \mathrm{Fw}$ & $881.5 \pm 72.6^{\mathrm{b}}$ & $1221.6 \pm 391.3^{b}$ & $2067.9 \pm 683.7^{\mathrm{ab}}$ & $3579.3 \pm 126.5^{\mathrm{a}}$ & $1453.0 \pm 354.7^{\mathrm{b}}$ \\
\hline Phosphorus & $\mathrm{mg} \mathrm{kg}^{-1} \mathrm{Fw}$ & $65.0 \pm 17.1^{\mathrm{b}}$ & $437.7 \pm 26.1^{\mathrm{a}}$ & $91.3 \pm 35.3^{b}$ & $406.5 \pm 10.5^{\mathrm{a}}$ & $96.3 \pm 27.8^{b}$ \\
\hline Sulfur & $\mathrm{mg} \mathrm{kg}^{-1} \mathrm{Fw}$ & $412.8 \pm 89.7^{\mathrm{ab}}$ & $499.7 \pm 54.4^{\mathrm{a}}$ & $579.6 \pm 25.7^{\mathrm{a}}$ & $204.8 \pm 14.9^{\mathrm{bc}}$ & $192.8 \pm 22.2^{c}$ \\
\hline Total phenols & mg GAE kg-1 Fw & $1320.8 \pm 101.6^{\mathrm{c}}$ & $3109.9 \pm 153.7^{\mathrm{a}}$ & $1391.6 \pm 118.9^{c}$ & $1053.8 \pm 41.0^{c}$ & $2309.7 \pm 266.7^{\mathrm{b}}$ \\
\hline Antioxidant activity & $\mathrm{mg} \mathrm{TE} \mathrm{kg}{ }^{-1} \mathrm{Fw}$ & $1033.3 \pm 82.8^{\mathrm{b}}$ & $4015.4 \pm 384.7^{\mathrm{a}}$ & $1311.5 \pm 70.5^{b}$ & $1592.5 \pm 60.4^{\mathrm{b}}$ & $3333.7 \pm 663.0^{\mathrm{a}}$ \\
\hline
\end{tabular}

Fw, fresh weight; GAE, gallic acid equivalents; TE, Trolox equivalents. Values are means \pm standard errors for each analysed parameter as determined from $n$ samples. ${ }^{\text {a-c }}$ Means followed by different letters in each row are significantly different ( $\mathrm{P}=0.05$; Tukey's test). 
high chloride and nitrate contents. Finally, cluster 5 comprises $S$. oleraceus, $B$. officinalis, and D. tenuifolia and is defined by high potassium levels.

To best explain the differences between these different clusters and to evaluate which of the main qualitative parameter(s) play the most important role(s) in determining these differences, linear discriminant analysis was applied. The 13 original variables (i.e., qualitative parameters) of the wild edible plants were reduced to two canonical variates $\left(\mathrm{CN}_{\mathrm{j}}\right)$ that represent $81.3 \%$ of the total variability in the data (Table 4): $57.7 \%$ for the first $\left(\mathrm{CN}_{1}\right)$ and $23.6 \%$ for the second $\left(\mathrm{CN}_{2}\right)$. To correctly interpret the relationships between $\mathrm{CN}_{\mathrm{j}}$ and the original variables, it is important to note that $\mathrm{CN}_{\mathrm{j}}$ are linear combinations of the original variables and that the canonical coefficients maximise the discrimination among the experimental factors under consideration using canonical coefficients. The original variable with the largest standardised canonical coefficient has the strongest impact on $\mathrm{CN}_{\mathrm{j}}$. $\mathrm{CN}_{1}$ was positively affected (high standardised canonical coefficient values) by chloride, phosphorus and protein contents and inversely correlated to the levels of dry matter, potassium and fluoride. In contrast, $\mathrm{CN}_{2}$ was mainly defined by phosphorus and calcium levels and the total phenol content (scores of $2.89,1.49$, and 2.47 , respectively) and by potassium levels and protein content to a different extent (scores of 1.26 and 0.96 , respectively). Coherent information can also be derived from the correlation matrix (Table 4) between the original variables and the new $\mathrm{CN}_{\mathrm{j}}$. To better interpret the ability of $\mathrm{CN}_{1}$ and $\mathrm{CN}_{2}$ to separate the clusters obtained from the cluster analysis, the selected $\mathrm{CN}_{\mathrm{j}}$ were represented graphically in a biplot (Figure 8), in which the canonical scores were plotted as symbols while the standardised canonical coefficients for each of the original variables were reported as vectors, that was used to interpret the results. According to correlation matrix results (Table 4), the original variables (i.e., sodium, sulfur and antioxidant activity) were not considered in the graphic interpretation because they did not significantly affect the $\mathrm{CNj}(\mathrm{P}<0.05)$.

\section{Discussion}

\section{Wild herbaceous edible plants}

This study was found that the quali-quantitative parameters of the wild species examined could make an important contribution to balancing and rationalising diets. In particular, our researcher showed that the edible wild plants contain numerous macro and micronutrients, such as phenols and other components that increase their antioxidant capacity. All the species analysed in the present study, except for B. vulgaris, can be considered low in sodium, which is recommended to reduce blood pressure and prevent heart disease (WHO, 2008). The potassium and magnesium levels are consistent with those reported by Bianco et al. (2009) but are higher than those reported by Renna et al. (2015). While most of calcium values were slightly higher than those reported in the literature (Tarantino et al., 2008). This might be due to the characteristics of the soil in the area, which tend to calcareous, with $\mathrm{pH}$ values from 7.7 to 8.2 .

The lowest level of nitrates in the present study was observed in the wild C. intybus, which was consistent with the data in the literature (Renna et al., 2015; Bianco, 2002). The highest nitrate accumulation was observed across all the species in the Brassicaceae family (i.e., D. tenuifolia, S. arvensis) and was in agreement with data reported in other studies (Cerruti et al., 1996;
A

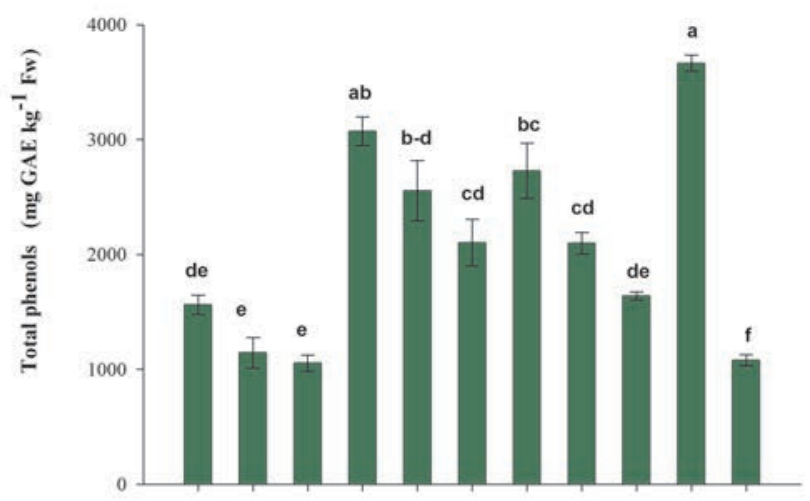

B

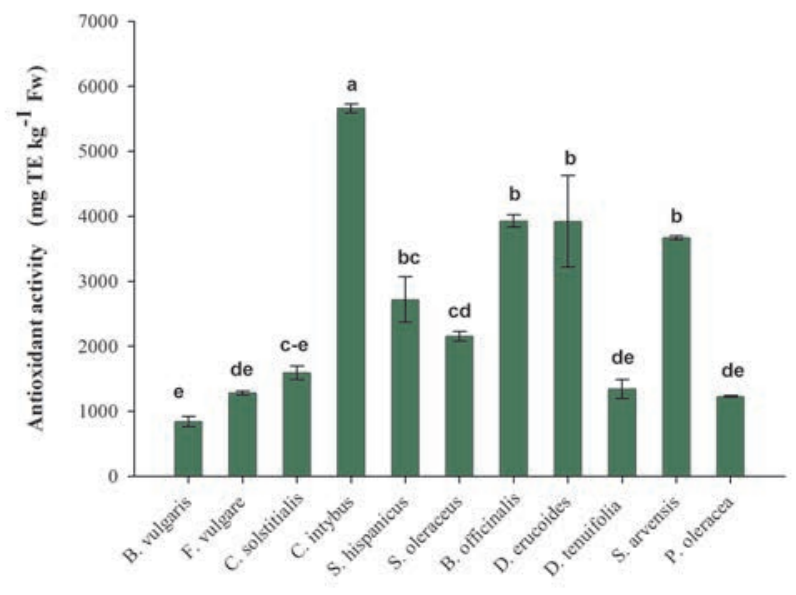

Figure 5. Total phenols (A) and antioxidant activities (B) in the fresh samples of the 11 wild edible plant species in the study. Data are means \pm standard errors for each analysed parameter as determined from 4 samples (replicates). Means followed by different letters are significantly different $(P=0.05$; Tukey's test).

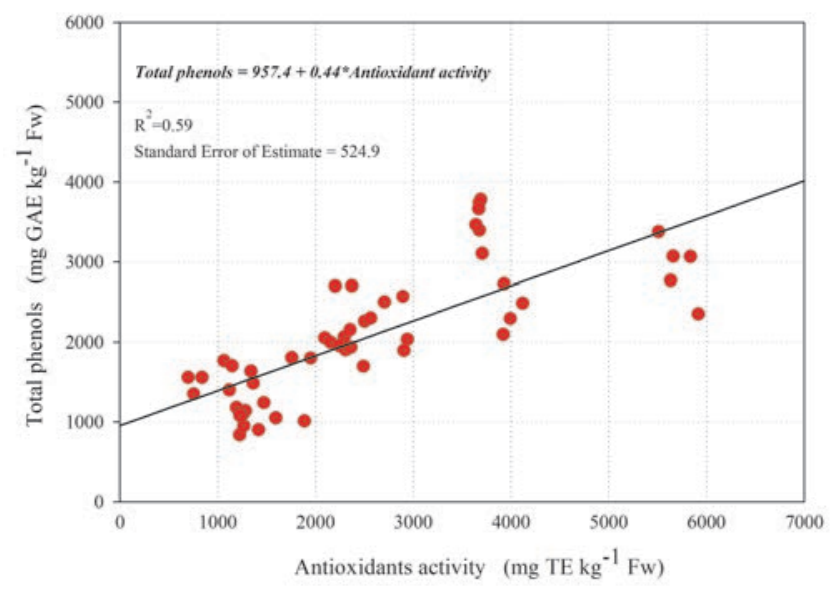

Figure 6. Linear regression analysis of total phenol content and antioxidant activity. 


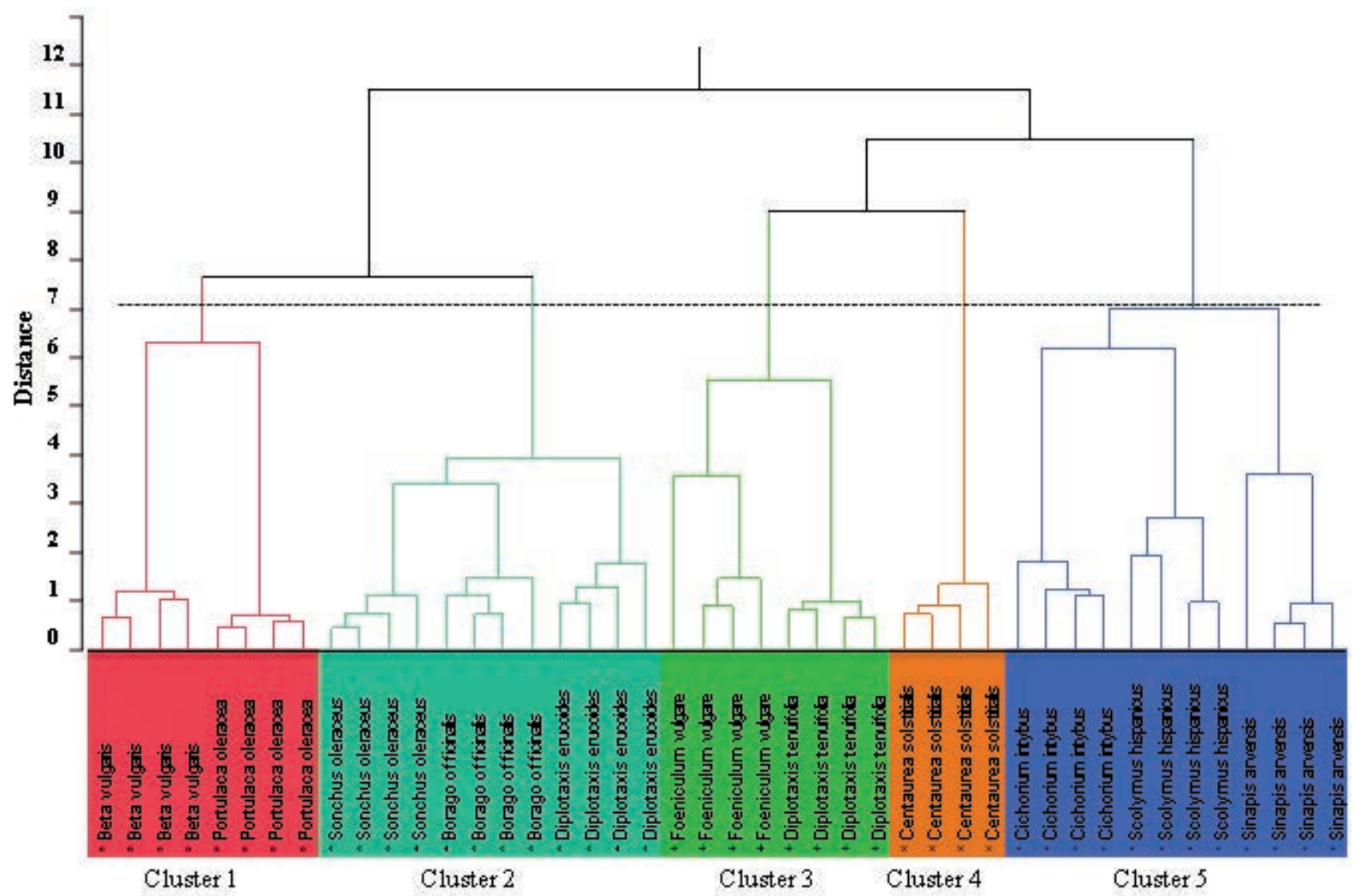

Figure 7. Dendrogram constructed from the cluster analysis of the qualitative parameters of the wild plant species.

Santamaria et al., 1998). Moreover, according to the classification proposed by Santamaria (2006), wild C. intybus falls within the group of vegetables considered to have low nitrate contents (200$\left.500 \mathrm{mg} \mathrm{kg}^{-1} \mathrm{Fw}\right)$. Similar values were also seen for $P$. oleracea, $B$. vulgaris, S. hispanicus, and F. vulgare.

Data obtained from wild plants (i.e. C. intybus, S. arvensis, and B. officinalis) showed the highest polyphenol contents as well as the greatest antioxidant capacities. In fact, the latter parameter is strictly related to the phenol content as stated by many authors (Di Venere et al., 2009; Sergio et al., 2016).

In general, the qualitative data reported in this study showed that wild edible species contain many of the so-called minor nutrients, such as phenols and antioxidant components, which can further improve an already-balanced diet. This can offer protection against degenerative processes because the wild species considered in this research could make a contribution towards the desired antioxidant capacity of approximately $5000 \mathrm{mg} \mathrm{TE} \mathrm{kg} \mathrm{Fw}^{-1} \mathrm{Fos}$ estimated by health authorities (INRAN, 2003). Furthermore, in addition to their antioxidant concentrations, all the analysed wild species are rich in phenolic components that increase their antioxidant capacity.

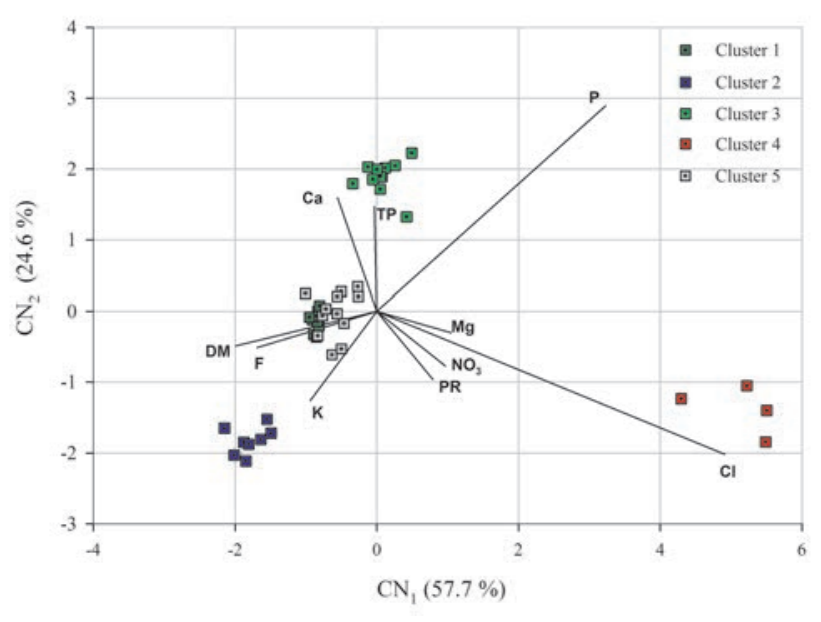

Figure 8. Linear discriminant analysis of the cluster analysis data. $\mathrm{DM}$, dry matter; $\mathrm{P}$, protein; $\mathrm{K}$, potassium; $\mathrm{Mg}$, magnesium; $\mathrm{Ca}$, calcium; F, fluorides; $\mathrm{NO}_{3}^{-}$, nitrates; $\mathrm{P}$, phosphorus; TP, total phenols. 


\section{Wild $v s$ cultivated herbaceous food plants}

In general, cation and anion contents have previously been reported to vary little among wild and cultivated species. This is probably because the uptake of these components strongly depends on botanical characteristics rather than different environmental and agronomic conditions.

Related to the nitrate contents, the wild species showed significantly lower levels compared to those of cultivated plants (C. intybus, B. officinalis and D. tenuifolia), which have received a certain amount of nitrogen fertilisation. Nitrogen fertilisation is one of the main factors affecting the accumulation of nitrates in vegetables (Santamaria et al., 1999; Weightman et al., 2012).

The total polyphenols and antioxidant activities were significantly higher in the wild plants (C. intybus and B. officinalis) compared to the cultivated plants. Phenol levels vary widely in vegetables depending several factors including the species, physiological stage, and location in terms of the conditions of the soil and the growth environment. In terms of the environment, plants are known to synthesise a greater array of these secondary compounds when they are exposed to several types of stress (e.g., water, saline, thermal, and nutritional) (European Commission, 2002), and wild plants would generally be subjected to greater stress than cultivated plants.

\section{Multivariate analysis of the qualitative parameters}

The ANOVA results reported above showed the effects of the experimental factor (i.e., species) on each individual qualitative variable. A multivariate analytical approach (i.e., cluster analysis and linear discriminant analysis) allowed these data to be integrated to evaluate which qualitative variables (considered simultaneously) contributed the most to the differences among the groups (i.e., species).

The graphical results of the linear discriminant analysis show that $\mathrm{CN}_{1}$ is very important for discriminating many of the clusters (especially clusters 2 vs 4 ). Therefore, the dry matter content; the chloride, phosphorus, potassium, and fluoride levels; and the protein content (i.e., all highly correlated to $\mathrm{CN}_{1}$; Table 4) effectively differentiated between many of these wild edible plant groups. $\mathrm{CN}_{2}$ enables the separation of clusters 2 and 3, showing greater importance than calcium and potassium levels and total phenol content (i.e., all highly correlated to $\mathrm{CN}_{2}$; Table 4). These qualitative parameters are the same as those used to characterised the different clusters in accordance with the ANOVA of the different cluster groups (Table 4).

\section{Conclusions}

The present study evaluated the protein, mineral levels polyphenol content and the antioxidant activity of the main wild herbaceous food species consumed in Foggia Province (southern Italy), some of which have not been previously investigated. Most of these analysed wild edible plant species were shown to be good sources of minerals. In particular, S. hispanicus was rich in calcium, potassium and magnesium, D. tenuifolia in phosphorus and sulfur, and $C$. solstitialis in chlorides.

Nitrates are known to be dangerous at high levels as they can form potentially carcinogenic nitrosamines, but their levels were very low in wild $C$. intybus compared to the levels in the other species. Among the plants analysed in this study, relatively high, although also variable, total polyphenol contents and antioxidant activity were observed in $S$. arvensis, C. intybus, B. officinalis, D. erucoides, and $S$. hispanicus.

For both $C$. intybus and B. officinalis, significantly higher values of the qualitative parameters were generally observed in wild plants than in cultivated plants. Indeed, wild C. intybus is of particular interest in terms of its qualitative profile, which is characterised by high polyphenol levels and high antioxidant activity. When combined with the low nitrate levels, this profile might account for the high nutritional quality and medicinal properties of

Table 4. Standardised coefficients (scores) and Pearson's correlation coefficients for the first two discriminant canonicals, considering the 13 qualitative variables of the wild edible plant species.

\begin{tabular}{|c|c|c|c|c|}
\hline \multirow[t]{2}{*}{ Original variable } & \multicolumn{2}{|c|}{ Standardised canonical coefficient } & \multicolumn{2}{|c|}{ Pearson's correlation coefficient } \\
\hline & $\mathrm{CN}_{1}$ & $\mathrm{CN}_{2}$ & $\mathrm{CN}_{1}$ & $\mathrm{CN}_{2}$ \\
\hline Dry matter & -1.99 & -0.49 & $-0.66 * * *$ & $-0.54^{* * *}$ \\
\hline Protein & 0.79 & -0.96 & $0.49 * *$ & $-0.47 * *$ \\
\hline Sodium & 0.22 & -0.35 & $0.10 \mathrm{~ns}$ & $-0.10 \mathrm{~ns}$ \\
\hline Potassium & -0.94 & -1.26 & $-0.30^{*}$ & $-0.41^{* *}$ \\
\hline Magnesium & 1.05 & -0.30 & $0.36^{*}$ & $0.01 n s$ \\
\hline Calcium & -0.55 & 1.49 & $-0.09 n s$ & $0.47^{* *}$ \\
\hline Fluorides & -1.69 & -0.51 & $-0.39 *$ & $-0.09 n s$ \\
\hline Chlorides & 4.91 & -2.02 & $0.82 * * *$ & $-0.42 * *$ \\
\hline Nitrates & 0.97 & -0.77 & $0.41^{* *}$ & $-0.48 * *$ \\
\hline Phosphorus & 3.23 & 2.89 & $0.60 * * *$ & $0.55^{* * *}$ \\
\hline Sulphur & 0.04 & -0.23 & $-0.14 n s$ & $-0.14 n s$ \\
\hline Total phenols & -0.03 & 1.47 & $-0.11 n s$ & $0.71^{* * *}$ \\
\hline Antioxidant activity & 0.21 & -0.27 & $0.01 \mathrm{~ns}$ & $-0.27 n s$ \\
\hline Percentage of variation explained & $57.7 \%$ & $24.6 \%$ & & \\
\hline Cumulative variation explained & - & $81.3 \%$ & & \\
\hline
\end{tabular}

$\mathrm{CN} 1$, discriminant canonical 1 ; CN2, discriminant canonical 2 . The corresponding percentages of the explained variation are also reported. ${ }^{*} \mathrm{P} \leq 0.05 ;{ }^{* *} \mathrm{P} \leq 0.01 ;{ }^{* * *} \mathrm{P} \leq 0.001 ; \mathrm{ns}$, correlation not significant $(\mathrm{P}>0.05)$. 
the species. Moreover, the value that consumers attribute to wild species for the preparation of particular traditional Italian dishes together with their high organoleptic and nutraceutical levels compared to commonly marketed cultivated species could be the basis for improving the links between rural communities and their plant genetic resources.

\section{References}

Aldenderfer M, Blashfiel, R, 1984. Cluster analysis. Sage, London, UK.

Aliotta G, 1987. Edible wild plants of Italy. Inform. Bot. 19:17-30.

Alloway BJ, 2004. Contamination of soils in domestic gardens and allotments: a brief review. Land Contam. Reclamat. 12:179-87.

Bianco VV, 1989. Specie erbacee della flora infestante pugliese utilizzabili come ortaggi e piante da condimento. In Atti e relazioni dell'Accademia pugliese delle Scienze. Fasano, Grafischena, 46:11-27.

Bianco VV, 1990. Le piante spontanee della flora italiana utilizzate come ortaggi. In: V.V. Bianco and F. Pimpini (eds.) Orticoltura. Patron Ed., Bologna, Italy, pp. 883-969.

Bianco VV, 1997. Specie erbacee spontanee eduli della flora pugliese. In atti del Convegno: la flora e la vegetazione spontanea della Puglia nella scienza, nell'arte e nella storia. Bari, 22-23 maggio. Fasano: Schena Ed., pp. 61-83.

Bianco VV, 2002. Nitrato in alcune specie spontanee eduli pugliesi. Colture Protette 31:42-46.

Bianco VV, Machackova M, 2002. Specie spontanee della flora italiana utilizzabili come ortaggi e piante di condimento. Atti VI Giorn. Sci. SOI, Spoleto (PG), pp. 435-6.

Bianco VV, Mariani R, Santamaria P, 2009. Piante spontanee nella cucina tradizionale molese. Storie, curiosità e ricette. Levante Ed., Bari, Italy.

Boari F, Cefola M, Di Gioia F, Pace B, Serio F, Cantore V, 2013. Effect of cooking methods on antioxidant activity and nitrate content of selected wild Mediterranean plants. Int. J. Food Sci. Nutr. 64:870-6.

Box, GEP, Cox DR, 1964. An analysis of transformations (with discussion). J.R. Stat. Soc. 26:211-50.

Brand-Williams W, Cuvelier ME, Berset C, 1995. Use of a free radical method to evaluate antioxidant activity. Lebensm. Wiss Technol.-Food. Sci. Technol. 28:25-30.

Cammareri M, Errico A, Sebastiano A, Conicella C, 2004. Genetic relationships among Aster species by multivariate analysis and AFLP markers. Hereditas 140:193-200.

Candido V, Castronuovo D, Fascetti S, Rosati L, Potenza G, 2017. Seed-propagated Muscari comosum (L.) Mill.: Effects of sowing date and growing conditions. Plant Biosyst. 3:484-92.

Conti F, Abbate G, Alessandrini A, Blasi C, 2005. Checklist of the Italian vascular flora. Palombi ed., Rome, Italy.

Cerruti G, Bertolé S, Casartelli A, D'Amato A, 1996. Nitrati e nitriti in ortaggi e aromatizzanti vegetali del commercio. La Difesa delle Piante 19:35-40.

Clark HF, Brabander DJ, Erdil RM, 2006. Sources, sinks and exposure pathways of lead in urban garden soil. J. Environ. Qual. 35:2066-74.

Cook NC, Samman S, 1996. Flavonoids-Chemistry, metabolism, cardioprotective effects, and dietary sources. Nutr. Biochem. 7:66-76

Di Venere D, Sergio L, Linsalata V, Pieralice M, Cardinali A, Cascarano N, Bianco VV, 2009. Proprietà antiossidanti di specie erbacee spontanee eduli. Atti III Convegno Nazionale Piante Mediterranee, Bari 27 settembre-1 ottobre 2006. Ital. J. Agron. 4(Suppl.4):635-40.

European Commission, 2002. Directive of the European Parliament and of the Council of 10 June 2002 on the approximation of the laws of the Member States relating to food supplements, 2002/46/EC. In: Official Journal, L 183, 12.7.2002.

Everitt B, 1980. Cluster analysis. Heinemann, London, UK.

Finkel T, Holbrook NJ, 2000. Oxidants, oxidative stress and the biology of ageing. Nature 408:239-47.

Guil Guerrero JL, Campra Madrid P, Torua Isasa ME, 1999. Mineral elements determination in wild edible plants. Ecol. Food Nutr. 38:209-22.

Hadjichambis ACH, Paraskeva-Hadijchambi D, Della A, Giusti ME, De Pasquale C, Lenzarini C, 2008. Wild and semidomesticate food plant consumption in seven circum-Mediterranean areas. Int. J. Food Sci. Nutr. 59:383-414.

INRAN, 2003. Linee guida per una sana alimentazione Italiana. Istituto Nazionale di Ricerca per gli Alimenti e la Nutrizione, Rome, Italy.

Leonti M, Nebel S, Rivera D, Heinrich M, 2006. Wild gathered food plants in the European Mediterranean: a comparative analysis. Econ. Bot. 60:130-42.

Marzi V, Tedone L, 2009. Fattori climatici e socio-economci nell'evoluzione del paesaggio agrario e forestale in ambiente mediterraneo. Ital. J. Agron. 4:23-30.

McCollum JP, 1992. Vegetable crops. Interstate Publishers, Inc., Danville, CA, USA.

McLachlan G, 1992. Discriminant analysis and statistical pattern recognition. John Wiley and Sons, New York, NY, USA.

Moore WC, Meyers DA, Wenzel SE, Teague GW, Li H, Li X, D'Agostino R, Castro, M, Curran-Everett D, Fitzpatrick AM, Gaston B, Jarjour NN, Sorkness R, Calhoun WJ, Chung KF, Comhair SA, Dweik RA, Israel E, Peters SP, Busse WW, Erzurum SC, Bleecker ER, National Heart, Lung, and Blood Institute's Severe Asthma Research Program, 2010. Identification of asthma phenotypes using cluster analysis in the Severe Asthma Research Program. Am. J. Respir. Crit. Care Med. 181:315-23.

Pardo de Santayana M, Tardìo J, Blanco E, Carvalho AM, Lastra JJ, San Miguel E, Morales R, 2007. Traditional knowledge of wild edible plants used in the northwest of the Iberian peninsula (Spain and Portugal): a comparative study. J. Ethnobiol. Ethnomed. 3:1-11.

Peterson J, Dwyner J, 1998. Flavonoids: dietary occurrence and biochemical activity. Nutr. Res. 18:1995-2018.

Pieroni A, Janiak V, Dürr CM, Lüdeke S, Trachsel E, Heinrich M, 2002. In vitro antioxidant activity of non-cultivated vegetables of ethnic Albanians in southern Italy. Phytother. Res. 16:467-73.

Podani J, 2007. Analisi ed esplorazione multivariata dei dati in ecologia e biologia. Liguori, Naples, Italy.

Renna M, 2017. Wild edible plants as a source of mineral elements in the daily diet. Progr. Nutr. 19:219-22.

Ranfa A, Maurizi A, Romano B, Bodesmo M, 2014. The importance of traditional uses and nutraceutical aspects of some edible wild plants in human nutrition. Plant Biosyst. 148:297-306.

Renna M, Cocozza C, Gonnella M, Abdelrahman H, Santamaria P, 2015. Elementar characterization of wild edible plants countryside and urban areas. Food Chem. 177:29-36.

Renna M, Gonnella M, Giannino D, Santamaria P, 2014. Quality evaluation of cook-chilled chicory stems (Cichorium intybus L., Catalogna group) by conventional and sous vide cooking methods. J. Sci. Food. Agric. 94:656-65. 
Santamaria P, 2006. Nitrate in vegetables: toxicity, content, intake and EC regulation. J. Sci. Food. Agric. 86:10-17.

Santamaria P, Elia A, Gonnella M, Parente A, Serio F, 1999. Accumulo di nitrati e produzione della rucola. Informatore Agrario 55:99-103.

Santamaria P, Elia A, Papa G, Serio F, 1998. Nitrate and ammonium nutrition in chicory and rocket salad plants. Plant Nutr. 21:1779-89.

Schaffer S, Schmitt-Schillig S, Müller WE, Eckert GP, 2005. Antioxidant properties of Mediterranean food plant extracts: geographical differences. J. Physiol. Pharmacol. 56:115-24.

Sergio L, Gatto MA, Spremulli L, Pieralice M, Linsalata V, Di Venere D, 2016. Packaging and storage conditions to extend the shelf life of semi-dried artichoke hearts. LWT - Food Sci. Technol. 72:277-84.

Singh G, Kawatra A, Sehgal S, 2001. Nutritional composition of selected green leafy vegetables, herbs and carrots. Plant Foods Hum. Nutr. 56:359-64.

Singleton VL, Rossi JA, 1965. Colorimetry of total phenolics with phosphomolybdic-phosphotungstic acid reagents. Am. J. Enol. Vitic. 16:144-58.

Tarantino E, Disciglio G, Tarantino A, 2011. Biodiversità e Agricoltura. Specie vegetali ecotipi varietà locali ed agro ecosistemi della Puglia. Facoltà di Agraria -Università degli Studi di Foggia. Tip. Rotostampa, Foggia, Italy.

Tarantino E, Frabboni L, Giuliani MM, Gatta G, Disciglio G,
Libutti A, Basso G, de Simone G, 2008. Opuscolo divulgativo Lotta alla desertificazione. Available from: http://www.minambiente.it/sites/default/files/archivio/biblioteca/La lotta_alla d esertificazione_in_Italia.pdf

Trichopoulou A, Vasilopouloua E, Holimanb P, Chamalidesc C, Foufac E, Kaloudisd T, Kromhoute D, Miskakid P, Petrochiloud I, Poulimac E, Stafilakisc K, Theophilouc D, 2000. Nutritional composition and flavonoid content of edible wild greens and green pies: a potential rich sources of antioxidant nutrients in the Mediterranean diet. Food Chem. 70:31923.

Vanzani P, Rossetto M, De Marco V, Sacchetti LE, Paoletti MG, Rigo A, 2011. Wild Mediterranean plants as traditional food: A valuable source of antioxidants. J. Food Sci. 76:46-51.

Vitalini S, Grande S, Visioli F, Agradi E, Fico G, Tome F, 2006. Antioxidant activity of wild plants collected in Valsesia, an alpine region of northern Italy. Phytother. Res. 20:576-80.

Webb A, 2002. Statistical pattern recognition (2nd ed.). John Wiley \& Sons, NY, USA.

Weightman RM, Huckle AJ, Roques SE, Ginsburg D, Dyer CJ, 2012. Factors influencing tissue nitrate concentration in fieldgrown wild rocket (Diplotaxis tenuifolia) in southern England. Food Addit. Contam. A 29:1425-35.

WHO, 2008. Worldwide prevalence of anaemia 1993-2005: WHO global database on anaemia. World Health Organization, Geneva, Switzerland. 